\title{
Old and New Drug Targets in Diabetic Retinopathy: From Biochemical Changes to Inflammation and Neurodegeneration
}

\author{
E.C. Leal ${ }^{1}$, A.R. Santiago ${ }^{1,2}$ and A.F. Ambrósio*,1,2 \\ ${ }^{1}$ Center for Ophthalmology of Coimbra, IBILI, Faculty of Medicine, University of Coimbra, Portugal \\ ${ }^{2}$ Center for Neuroscience and Cell Biology, University of Coimbra, Portugal
}

\begin{abstract}
Diabetic Retinopathy (DR) is a major complication of diabetes and is a leading cause of blindness in western countries. DR has been considered a microvascular disease, and the blood-retinal barrier breakdown is a hallmark of this disease. The available treatments are scarce and not very effective. Despite the attempts to control blood glucose levels and blood pressure, many diabetic patients are affected by DR, which progresses to more severe forms of disease, where laser photocoagulation therapy is needed. DR has a huge psychological impact in patients and tremendous economic and social costs. Taking this into account, the scientific community is committed to find a treatment to DR. Understanding the cellular and molecular mechanisms underlying the pathogenesis of DR will facilitate the development of strategies to prevent, or at least to delay the progression of the disease. The involvement of the polyol pathway, advanced glycation end products, protein kinase $\mathrm{C}$ and oxidative stress in the pathogenesis of $\mathrm{DR}$ is well-documented, and several clinical trials have been conducted to test the efficacy of various drugs. More recent findings also demonstrate that DR has characteristics of chronic inflammatory disease and neurodegenerative disease, which increases the opportunity of intervention at the pharmacological level. This review presents past and recent evidences demonstrating the involvement of different molecules and processes in DR, and how different approaches and pharmacological tools have been used to prevent retinal cell dysfunction.
\end{abstract}

Keywords: Diabetic retinopathy, blood-retinal barrier, polyol pathway, advanced glycation end products (AGEs), protein kinase C (PKC), oxidative stress, inflammation, neurodegeneration.

\section{INTRODUCTION}

It is estimated that diabetes affects around 200 million people worldwide, and the number of people affected by diabetes will continue to increase over the next years. Particularly, the prevalence of type 2 diabetes (non-insulindependent) is increasing at an alarming rate. Diabetic Retinopathy (DR) is one of the most common complications of diabetes, and is the leading cause of blindness in western countries [1,2].

Despite recent progresses in understanding the cellular and molecular mechanisms underlying the pathogenesis of $\mathrm{DR}$, the disease is still neither preventable nor curable. The scientific community is committed to this field of research, and there has been a concerted effort to develop new strategies to treat DR. Hyperglycemia is considered to be the primary pathogenic factor in the development of DR. However, the mechanisms by which high blood glucose levels cause the disease and its progression are not clear yet. In fact, the development of therapeutic strategies to treat DR strictly depends on our understanding of the pathogenic process.

DR is clinically characterized by microvascular dysfunction, with basement membrane thickening of retinal vessels, loss of pericytes and endothelial cells, blood-retinal barrier (BRB) breakdown, capillary non-perfusion,

*Address correspondence to the author at the Center for Ophthalmology of Coimbra, IBILI, Faculty of Medicine, University of Coimbra, Azinhaga de Santa Comba, Celas, 3000-354 Coimbra, Portugal; Tel: +351 239480 222; Fax: +351 239480 280; E-mail: fambrosio@ibili.uc.pt microaneurysms, hemorrhages, lipid exudates, cotton-wool spots and neovascularization (proliferative DR). In the case of proliferative DR, the new vessel walls are weak, allowing the blood to leak out of the vessels, which results in vitreous hemorrhage and subsequent detachment of the retina [3]. Visual impairment is usually associated with the later stages, and is mainly due to the formation of new vessels on the surface of the retina and macular edema.

DR has been considered a microvascular disease, but recent findings clearly indicate that other components of the retina, such as neurons and glial cells, may be also affected $[4,5]$. Thus, multiple cell types in the retina are affected by diabetes and multiple pathogenic processes occur at the same time.

After 15 years with diabetes, approximately $80 \%$ of patients have retinopathy, and therefore prevention is the key word. With a good control of glycemia, blood pressure and normalization of lipids, it is possible to delay the onset and progression of the disease, but in some cases, it is difficult to achieve good metabolic control. Laser photocoagulation is usually the recommended treatment for patients with proliferative DR or severe macular edema, but in a high percentage of patients, retinopathy continues to progress and the treatment needs to be repeated. Photocoagulation is a rather aggressive technique since it destroys the retina [2]. Therefore, the development of non-invasive therapies to prevent and treat DR is needed, and remains a priority for eye research. In fact, since the appearance of laser surgery, there have been no major advances in the treatment of this disease, despite several clinical trials on a variety of drugs. 
In addition to morphological alterations, various biochemical and molecular changes have been identified in human diabetic retinas and in animal models [6]. Hyperglycemia stimulates protein kinase C (PKC), polyol pathway, formation of advanced glycation end products (AGEs) and cellular oxidative stress [7]. A large body of evidence also indicates that DR has many features of neurodegeneration and chronic inflammation, such as increased nitric oxide production, intracellular adhesion molecule-1 (ICAM-1) upregulation and leukostasis [4,8]. All these processes and molecules are potential therapeutic targets, and in recent years, several drugs have been tested in patients with diabetes.

This review will focus on molecular and cellular changes, and on biochemical pathways activated by hyperglycemia in the retina, as potential targets in the treatment of DR. Also, studies involving human subjects in which some drugs with potential use in the therapy of this disease have been tested, will be presented and discussed.

\section{BLOOD-RETINAL BARRIER BREAKDOWN AND NEOVASCULARIZATION: ANTI-VEGF THERAPY AND THE POSSIBLE USE OF CORTICOSTEROIDS}

Homeostasis is essential for the normal function of the retina and is maintained by both inner and outer BRB that control water and solute flux to the retinal parenchyma and protect the retina from compositional fluctuations within the blood. The BRB is formed by highly specialized endothelial or epithelial cells, which restrict the diffusion of molecules by an assembly of proteins that constitutes the functional tight junctions between cells [9]. Tight junctions are composed of several transmembrane proteins, such as occludin, claudins and junctional adhesion molecule (JAM). Other proteins, localized in peripheral cytoplasm, including zonula occludens (ZO)-1, $\mathrm{ZO}-2$ and $\mathrm{ZO}-3$, act through multiple protein-protein interactions, and organize the tight junction complex and provide the interaction with components of the cytoskeleton $[10,11]$.

The breakdown of BRB is an early event in DR, leading to macular edema in more advanced stages of the pathology [12]. Vascular endothelial growth factor (VEGF) is considered to be a major factor in the breakdown of BRB [13]. However, other permeabilizing factors such as histamine, interleukin-1 beta (IL-1 $\beta$ ) and tumor necrosis factor alpha (TNF- $\alpha$ ) have also been implicated [14-16]. VEGF is increased in the eyes of diabetic patients and diabetic rats at the early stages of DR, and this observation was correlated with increased vascular permeability [17-19]. VEGF has also been found in aqueous and vitreous humor of patients with proliferative DR [20].

Inhibition of VEGF with specific VEGF-neutralizing soluble constructs can prevent the increase in BRB permeability induced by diabetes, clearly indicating that VEGF has a key role in this pathology [19,21]. Growth factors, such as transforming growth factor alpha (TGF- $\alpha$ ), TNF- $\alpha$, insulin-like growth factor 1 (IGF-1), and interleukins, AGEs and reactive oxygen species (ROS) have been shown to be upregulated in DR, and induce VEGF overexpression [22-27]. However, it is not well-understood how these factors lead to VEGF overexpression.
The VEGF gene produces alternatively spliced mRNA variants, leading to at least three distinct major VEGF isoforms [28]. The biological effects of VEGF are mediated by at least two tyrosine kinase receptors, also known as VEGF receptor 1 (VEGF-R1) and VEGF receptor 2 (VEGFR2) [28,29].

Several lines of evidences suggest that VEGF induces retinal permeability by altering tight junction protein complexes. Both diabetes and VEGF reduce occludin and $\mathrm{ZO}-1$ content in various experimental models and alter tight junction assembly [30,31]. Also, VEGF might regulate vessel permeability by increasing the phosphorylation of tight junction proteins, namely occludin and ZO-1 [30].

The identification of mediators that regulate VEGFinduced BRB breakdown is important for a potential pharmacological intervention. It was shown that VEGF overexpression and $\mathrm{BRB}$ breakdown are correlated with increased expression of both endothelial and neuronal nitric oxide synthase (eNOS and nNOS). Moreover, inhibiting nitric oxide synthase or scavenging peroxynitrite could prevent the alterations in barrier permeability [16,32,33]. Increased activity and expression of inducible NOS (iNOS) and cyclooxygenase-2 (COX-2) were also found in diabetic retinas [34]. These observations indicate that nitric oxide and peroxynitrite formation are involved in the pathogenesis of DR.

Capillary occlusion occurring in the early stages of DR is believed to play an important role in the progression of the disease [35]. Capillary occlusion could lead to hypoxia of retinal tissue, promoting an upregulation of growth factors, such as VEGF, and consequent formation of new vessels $[36,37]$. Therefore, in addition to its role as a permeabilizing agent, VEGF is also involved in the formation of new vessels in diabetic retinas. It is well-known that VEGF is upregulated by hypoxia and stimulates endothelial cell migration and proliferation [38,39]. Multiple stimulatory factors may contribute to the development of retinal neovascularization, but VEGF plays a critical role. Signaling through VEGF receptors is both necessary and sufficient for development of retinal neovascularization [40-42].

Blocking VEGF synthesis and vitreal injection of antiVEGF antibodies prevented retinal neovascularization in animal models [20]. Many approaches to inhibit VEGF action are being considered. One strategy is to inject relatively large inhibitors, such as aptamers or Fab fragments of anti-VEGF antibodies directly into the eye [43,44]. Another strategy is to avoid repeated intraocular injections by systemic administration of small molecule VEGF antagonists $[41,42,45]$. Soluble VEGF receptors provide a specific way to reduce VEGF bioavailability, and some studies have demonstrated that the extracellular domain of VEGF-R1 has antiangiogenic activity [46,47]. However, a disadvantage is that soluble VEGF-R1 is rapidly cleared. Saishin et al. [21] found that the clearance slows when ligand-binding domains of VEGF receptors linked to the Fc portion of $\operatorname{IgG}$ are used, and neovascularization is suppressed. Also, inhibition of VEGF receptor tyrosine kinase activity seems to be promising, not only for cancer research but also for a potential therapeutic use in the treatment of the vasoproliferative phase of DR. Studies using mouse models of oxygen-induced retinopathy and 
ischemia-induced retinopathy have shown that local treatment with specific receptor kinase inhibitors decrease retinal neovascularization $[48,49]$.

Pharmacological attenuation of VEGF effects and the use of corticosteroids in the treatment of macular edema associated with DR are being studied. Corticosteroids, a class of substances with anti-inflammatory properties, have been demonstrated to inhibit the expression of the VEGF gene. The platelet derived growth factor (PDGF)-induced expression of VEGF in cultures of human aortic vascular smooth muscle cells was inhibited by corticosteroids in a concentration-dependent manner [50]. Also, a recent study showed that intravitreous administration of triamcinolone reduces VEGF levels in the vitreous of patients with various degrees of DR and diabetic macular edema, and causes regression of active neovascularization [51]. In vitro studies demonstrated that corticosteroids increase the expression of tight junction proteins, namely occludin and ZO-1, and they can also reverse occludin phosphorylation [52,53].

The evidences presented here demonstrates the importance of VEGF in the pathogenesis of DR. In the early phase of DR, it acts as a permeabilizing factor, increasing the permeability of BRB, and at the later stages, it promotes neovascularization. Several studies pointed out that it is possible to regulate VEGF activity using different strategies, and in some cases, the results obtained are quite promising. The application of these approaches to humans still needs to be validated, but the advances obtained in cancer research and treatment in recent years may be helpful to people suffering from DR. It must be emphasized that VEGF does not act alone, and other molecules regulating or regulated by VEGF might be also considered good molecular targets, since it will also be possible indirectly to block, totally or partially, VEGF action.

\section{INHIBITING ALDOSE REDUCTASE ACTIVITY}

In the retina, the glycolytic pathway is overwhelmed in prolonged hyperglycemia, which favors the production of sorbitol by aldose reductase (AR). Sorbitol is further oxidized to fructose by sorbitol dehydrogenase, increasing the NADH/NAD ${ }^{+}$ratio [54]. This increase creates a state called "pseudohypoxia", which may favor increased free radical production, decreased nitric oxide synthesis and defective DNA repair $[55,56]$.

Polymorphisms of AR gene may account for individual variations in the susceptibility to DR [57]. Aldose reductase seems to be a key enzyme in the development of DR, since several AR inhibitors (ARIs), such as alresatin, sorbinil, ponalrestat, tolrestat, epalrestat, fidarestat and zenalestat had proven to be effective in experimental diabetes [58,59]. However, studies with diabetic patients have failed to prove any success. The Sorbinil Retinopathy Trial Research Group attempted to show that sorbinil could slow the progression of DR, however, the results failed to demonstrate the efficacy of this drug at the end of the three-year follow-up study [60]. Moreover, sorbinil was poorly tolerated, and significant secondary effects were observed, which make the use of this drug in humans problematic.

In humans with diabetic neuropathy and in diabetic animals, ARIs improved the velocity of nerve conduction and increased the regeneration of damaged axons [61,62]. However, clinical trials with sorbinil only caused small increases in conduction velocity [63-65]. Toxicity may pose a problem in the use of some AR inhibitors, as was demonstrated with sorbinil, which caused hypersensitivity reactions in 10 percent of patients. Even though the benefits of these drugs are limited, they may have a role in preventing diabetes-related diseases, such as DR, or in easing the symptoms of some patients.

\section{INTERVENTION AT THE LEVEL OF ADVANCED GLYCATION END PRODUCTS (AGES)}

Glucose can react with free amino groups to form Schiff base adducts and Amadori products. In biological systems, these intermediates are freely reversible and therefore exist in equilibrium that is proportional to the amount of free glucose. As a result, the levels of Amadori products in diabetic patients are usually two- to threefold higher than in their non-diabetic counterparts, but they do not accumulate indefinitely in long-lived macromolecules and there is no correlation between these adducts formation on tissues and diabetic complications [66].

Non-enzymatic condensation reactions between reducing sugars and amino groups or N-terminal groups also lead to advanced glycation end products formation [67], which can accumulate in cells over prolonged periods. AGEs formation on proteins, lipids, and DNA can have serious consequences for macromolecular function during diabetes and aging [6870]. Moreover, AGEs can interact with specific AGEs receptors and lead to oxidative stress and activation of nuclear factor kappa B (NF- $\kappa \mathrm{B})$ [71].

AGEs are known to accumulate in the diabetic retina where they may have important effects on retinal vascular cell function, as determined by a growing number of in vitro and in vivo studies [72,73]. Pentosidine is one of the AGEs found in the vitreous of patients with proliferative DR, and there is a high correlation between its levels and IL-6 levels [74], suggesting that increased formation of AGEs in the vitreous may be involved in the development of DR by inducing the production of IL-6 from retinal Müller cells. Accumulation of fructosyl-lysine was found in the kidney, retina and peripheral nerve of diabetic rats [75]. AGEs and/or late Amadori products have been localized in the neuroglia of diabetics [76], and they may have important, albeit poorly understood effects on neural dysfunction during retinopathy. AGEs were also reported to induce apoptosis in retinal pericytes in culture [77].

The therapeutic strategies that can be addressed using the prominent pathological role of AGEs are: prevention of AGEs formation, reduction of AGE receptor-ligand interactions or breaking established AGE crosslinks. Aminoguanidine, a potent inhibitor of AGE crosslinks, has been shown to be effective at preventing capillary closure, microaneurysm formation, basement membrane thickening and depletion of nitric oxide synthase [78-83]. Aminoguanidine was evaluated in a multicenter clinical trial where it achieved significant lowering of urinary albumin and slowed the progression of nephropathy and retinopathy [84]. Nevertheless, it is important to mention that this drug has many non-specific effects, including the inhibition of 
inducible nitric oxide synthase and semicarbazide-sensitive amine oxidase $[85,86]$.

The use of AGEs crosslink breakers allows preaccumulated AGEs clearance via the kidney. AGEs crosslink breakers, such as N-phenacylthiazolium bromide and ALT11, attack dicarbonylderived crosslinks in vitro and reduce tissue AGEs in experimental diabetes [87-89]. ALT-711 has been shown to ameliorate myocardial stiffness in aged dogs [90] and improved the ability of the carotid artery to expand during systole in diabetic rats [88]. In clinical trials, ALT711 improved arterial compliance in aged patients with measurable cardiovascular stiffening [84].

Although several lines of evidence demonstrate that therapies against AGEs have beneficial effects in several complications of diabetes, there is not a particular drug that has proved to be effective, and without significant secondary effects in the treatment of DR.

\section{Benfotiamine: High Expectations}

Benfotiamine is a lipid-soluble derivative of vitamin B1 with high bioavailability that can block the production of AGEs [91,92]. It was reported that high-dose therapy with thiamine and benfotiamine suppressed the accumulation of AGEs during diabetic nephropathy, and therefore may be a new approach to prevent the development of diabetic complications [93]. In a clinical trial with diabetic patients, benfotiamine used in combination of vitamin B6/B12 improved nerve conduction velocity in the peroneal nerve [94]. Benfotiamine and thiamine also prevented apoptosis induced by high glucose in human umbilical vein endothelial cells (HUVECs) and bovine retinal pericytes [95]. In the retina, it was suggested that benfotiamine prevents activation of the hexosamine pathway and the diacylglycerol-protein kinase C (DAG-PKC) pathway, and intracellular AGEs formation [96]. Whether benfotiamine can be used in the pharmacological prevention or treatment of the vascular complications of diabetes remains to be established.

\section{PROTEIN KINASE C: ANOTHER IMPORTANT PLAYER IN DR}

The protein kinase $\mathrm{C}$ family is a large group of serine/threonine kinases. Their function is to phosphorylate specific sites on protein targets, which is an important regulatory system for activating or deactivating enzymes, receptor pathways, and transcription factors controlling gene expression. Different enzymes of this class require the specific activation by second messengers, such as diacylglycerol (DAG). The PKC family is widely distributed throughout the body, and a generalized inhibitor of PKC is likely to have serious systemic consequences. However, the effect of specific inhibitors for a small class of PKC might have specific targets (such as organs or biochemical pathways), and therapeutical effects could be more effective and with less side effects.

The activation of PKC $\beta$ isoform (PKC $\beta$ ) has been implicated in the pathogenesis of DR [97-100]. It has been shown that DAG levels are increased and PKC $\beta$ is activated in the retinas from diabetic animals, and also in bovine retinal endothelial cells (BRECs) exposed to high glucose [99-101].
PKC $\beta$ activation might act as both modulator of VEGF action and stimulator of VEGF expression [102]. Intravitreal injection of VEGF induces retinal vessel permeability in non-diabetic rats, and this effect can be suppressed by intravitreal or oral administration of LY333531, a specific inhibitor of PKC $\beta$, or the general PKC inhibitor GF109203X [103]. In addition, the intravitreal injection of a $\mathrm{PKC}$ activator could induce the breakdown of BRB in nondiabetic rats [103]. Otherwise, the inhibition of PKC prevents glucose-induced increase in VEGF expression in vitro $[104,105]$. The intraperitoneal administration of a PKC inhibitor decreased retinal vessel permeability and retinal VEGF expression in diabetic rats [105]. Also, intravitreal injection of GF109203X decreased VEGF expression and retinal permeability in diabetic rats [106]. So, PKC inhibitors can prevent or reverse BRB breakdown by inhibiting VEGF expression or by interfering at the level of the intracellular signal transduction cascade initiated by VEGF.

The adhesion of leukocytes to endothelial cells is increased in diabetes, and this process seems to be mediated by adhesion molecules, such as ICAM-1 [107]. Some studies have suggested that PKC is also involved in the expression of adhesion molecules in endothelial cells. Lane et al. [108] demonstrated that PKC upregulates ICAM-1 expression in HUVECs and increases leukocyte adhesion to endothelial cells. The expression of vascular cell adhesion molecule-1 (VCAM-1) also seems to be regulated by PKC [109]. Furthermore, PKC inhibition has been shown to reduce glucose-induced leukocyte adhesion in vitro [110], and the PKC inhibitor LY333531 inhibits leukocyte entrapment in diabetic retina [111].

These studies conducted in a variety of experimental models in vitro and in vivo have demonstrated the involvement of PKC $\beta$ in DR. These observations have led to a possibly promising therapy using oral inhibitors of $\mathrm{PKC} \beta$ isoform. Clinical trials with $\mathrm{PKC} \beta$ antagonists are currently under way, to test their toxicity and effectiveness in suppressing diabetic complications. However, preliminary data with LY333531, there appears to be no effect on retinopathy progression in patients with moderate to severe non-proliferative DR [112]. These results could be explained by consideration that the causes of diabetic complications are multifactorial in nature, with other factors such oxidative stress, glycation end products and others also playing key roles. This reinforces the idea that DR treatment probably requires a multidrug therapy.

\section{ANTIOXIDANTS THERAPEUTICAL AGENTS IN DR}

POTENTIAL

Oxidative stress is believed to play a significant role in the pathogenesis of DR. Since the beginning of the last decade, a large body of evidence has demonstrated and confirmed that ROS play an important role in the development of DR, and therefore strategies conducted to prevent the deleterious effects caused by free radicals have been considered as potential treatments of this disease.

Increased oxidative stress might result from increased generation of free radicals and/or from an impairment of the antioxidant defense system. Several reports have shown that diabetes increases the formation of free radicals in the retina 
$[113,114]$. The excess of glucose leads to glucose autooxidation, and this is a main source of free radicals. Increased levels of thiobarbituric acid-reacting substances (TBARS), which are markers of oxidative stress, and decreased levels of superoxide dismutase (SOD) and glutathione peroxidase, were found in serum samples obtained from diabetic patients, when compared with control subjects, but no significant association was found between the levels of these substances and the severity of retinopathy [115]. In diabetic rats, an increase in the levels of TBARS and a decrease in glutathione levels in the retina were also found [116]. The increase in the levels of TBARS, glutamate and nitric oxide were inhibited in rats receiving a diet supplemented with a mixture of antioxidants $[117,114]$. Increased levels of TBARS were also found in BRECs exposed to high glucose concentrations, and the presence of the antioxidant $\mathrm{N}$-acetyl cysteine inhibited the formation of TBARS [114]. It seems that mitochondria are responsible for the elevation in the production of superoxide anions in diabetic retinas, and in cultured retinal Müeller cells and endothelial cells exposed to high levels of glucose [118].

Increased levels of VEGF in the retinas of diabetic rats were attenuated by two antioxidants, alpha-lipoic acid and taurine [119], suggesting that oxidative stress is involved in the overproduction of VEGF. These antioxidants also decreased the formation of lipid peroxidation products, such as malondialdehyde and 4-hydroxyalkenal.

As with VEGF, the increase in the activity of the polyol pathway caused by hyperglycemia is associated with the breakdown of blood-retinal barrier. The increase in the activity of this pathway, mainly due to increased activity of aldose reductase, may be one origin of excessive ROS production [120]. Fidarestat, an inhibitor of aldose reductase, arrested lipid peroxidation in the retinas of diabetic rats, essentially due to an increase in the activity of several antioxidant enzymes rather than changes in reduced glutathione, oxidized glutathione, ascorbate or dehydroascorbate concentrations. In BRECs, fidarestat also inhibited the production of ROS induced by high glucose [120]. These results indicate that increased aldose reductase activity contributes to retinal oxidative stress and retinal damage.

Apoptosis of retinal pericytes and endothelial cells contributes to retinal microvessels, obliteration and increased permeability of the BRB. Recently, it was found that caspase- 3 , an executioner enzyme of apoptosis, is activated in the retinas of alloxan diabetic rats and in cultured endothelial cells and pericytes exposed to high glucose [121]. Feeding rats with a diet supplemented with several antioxidants, including Trolox, alpha-tocopherol, N-acetyl cysteine, ascorbic acid, beta-carotene and selenium, or incubating cells with the antioxidants, inhibited the increase of caspase-3 activity, suggesting that oxidative stress is involved in the activation of caspase- 3 and apoptosis of endothelial cells and pericytes. Also, long-term administration of alpha-lipoic acid to diabetic rats has beneficial effects on capillary cell apoptosis and on the number of acellular capillaries in the retina, due to inhibition of nitrotyrosine and oxidatively modified DNA accumulation [122]. The number of pericytes present in retinal vessels was also partially restored in diabetic rats treated with trolox, an amphipathic antioxidant [123]. This group of results clearly indicates that oxidative stress is involved in microvascular cell loss in the course of DR.

The administration of a mixture of antioxidants also inhibited the activation of NF-kB, a transcription factor involved in the regulation of a large number of genes, suggesting that the beneficial effects of antioxidants might involve inhibition of NF-kB activation [124].

As mentioned before, the possibility that endogenous free radical scavengers are diminished in diabetic retinas must also be demonstrated. Almost two decades ago, Jennings et al. [125] demonstrated that the levels of ascorbic acid, a scavenger of free radicals, are significantly decreased in diabetic patients when compared to controls, suggesting that diabetics may be less able to prevent oxidative damage due to increased oxidative stress. The activities of glutathione reductase, glutathione peroxidase, SOD and catalase were decreased in the retinas of diabetic or galactosemic rats, but the activities of glutathione synthetase and gamma-glutamyl cysteine synthetase were unaffected [126]. Administration of vitamin $\mathrm{C}$ and $\mathrm{E}$ prevented the inhibition of those enzymes activities in diabetic animals, but in galactosemic rats, only SOD activity was restored to normal values. The levels of glutathione were also decreased in the retinas of non-obese, spontaneous non-insulindependent Goto-Kakizaki diabetic rats [127]. Using cultured BRECs and pericytes, Paget et al. [70] have shown that high glucose decreases glutathione peroxidase activity in endothelial cells, but no changes were observed in retinal pericytes.

The expression of several antioxidant enzymes was also determined by quantitative RT-PCR assay in purified pericytes, isolated from diabetic and non-diabetic donors. The pericytes isolated from the retinas of diabetic donors highly expressed a death protease, which is indicative of the activation of an apoptotic pathway in these cells. In diabetic pericytes, an upregulation of glutathione peroxidase, a downregulation of glutathione reductase and $\mathrm{CuZnSOD}$ were observed, while the mRNA levels of MnSOD and catalase did not differ significantly from pericytes isolated from nondiabetic donors [128]. These results suggest that there is an impairment of the antioxidant defense system in diabetic pericytes, but the upregulation of glutathione peroxidase indicates that there is a compensatory mechanism against increased levels of free radicals. These observations clearly demonstrate that the breakdown of the antioxidant system in pericytes from diabetic retinas is involved in pericyte dropout, which is considered a hallmark of DR and is one of the earliest changes observed in diabetic retinas.

The evidence presented here clearly demonstrates that oxidative stress plays a key role in DR. Increased production of ROS, formation of TBARS and lipid peroxidation, associated with a decrease in the activity of several antioxidant enzymes and in the amount of endogenous molecules with antioxidant properties, are characteristics of diabetic retinas or retinal cells exposed to high levels of glucose. Antioxidants prevent or at least inhibit, some retinal metabolic abnormalities and pathological changes induced by hyperglycemia, such as the breakdown of BRB, microvascular cell death and the formation of acellular capillaries, as demonstrated by using in vitro and animal 
models. Therefore, it is reasonable to think that an antioxidative therapy may be useful in the prevention of retinal damage, and some antioxidants may be considered as an adjunct therapy to prevent vision loss in diabetic patients. The mechanisms by which antioxidants inhibit the development of retinopathy caused by diabetes are nor clear yet, and need further investigation. It seems that free radicals act at various levels inside the cells, increasing the production of VEGF and activating NF- $\kappa \mathrm{B}$, for example. A key element taken from animal studies indicates that increasing the diversity of anti-oxidants provides more effective protection than using a single antioxidant. Whether antioxidants can prevent or delay retinal damage caused by diabetes in humans, has not been established yet, since the studies with human subjects are somewhat controversial.

Clinical studies have shown that high doses of vitamin $\mathrm{E}$ can apparently reverse some of changes in the retinal vessels, probably because vitamin E decreases PKC and DAG levels [129]. Treatment of diabetic patients with Vitamin E normalizes retinal blood flow, appearing to be effective in normalizing retinal hemodynamic abnormalities [130]. It was also shown that chronic administration of Vitamin $\mathrm{E}$ improves metabolic control and reduces protein glycation $[131,132]$. The potential use of selenium and Ginkgo biloba in the treatment of DR has also been considered, but there is no substantial experimental or clinical evidence clearly showing the beneficial effects of these compounds $[133,134]$.

Calcium dobesilate (CD; Doxium) has been used in the treatment of DR in more than 60 countries [135-137]. Calcium dobesilate is considered a highly effective angioprotective drug, but its mechanism(s) of action is still poorly understood. Calcium dobesilate decreases retinal albumin leakage, the formation of advanced glycation end products and VEGF overexpression in diabetic rat retinas [138]. These effects seem to be correlated with its antioxidant properties. In fact, $\mathrm{CD}$ was shown to scavenge hydroxyl radicals in vitro at therapeutically relevant concentrations, and to scavenge superoxide anions, but at higher concentrations [139]. Also, CD enhances the levels of glutathione in human peripheral blood mononuclear cells exposed to a highly reducing sugar 2-deoxy-D-ribose, thus decreasing the lipid peroxidation [140]. Although these findings suggest that the main mechanism of action of CD is as a free radical scavenger, other mechanisms might be involved in its vasoprotective effects.

Several clinical studies have shown that after long-term oral treatment CD delays the progression of DR. Calcium dobesilate decreases blood viscosity and microvascular hyperpermeability of retinal vessels, thus stabilizing BRB permeability and preventing both intra and extraretinal hemorrhages $[135,136,141,142]$. Beneficial effects were also observed in animal studies [138,143].

All the evidence presented here indicates that antioxidants may provide additional benefits in reducing the risk for developing DR. However, there is at present no substantial and clinical evidence to justify the clinical use of these drugs. Nevertheless, patients with diabetes might be encouraged to consume fruits and vegetables enriched in antioxidants, or even supplements of vitamins.

\section{ANGIOTENSIN CONVERTING ENZYME (ACE) INHIBITORS}

The renin-angiotensin system (RAS) plays a central role in blood pressure regulation. Most diabetic patients are also affected by hypertension [144], and elevated serum levels of angiotensin converting enzyme (ACE) have been found in type 1 diabetic subjects with retinopathy, especially in those with proliferative retinopathy, which suggests that elevated ACE levels may be a potential cause of retinal vascular damage in diabetes [145-148]. Indeed, it was shown that strict control of blood pressure and the use of an ACE inhibitor is effective in reducing the progression of DR and vision loss [149].

Hypertension might contribute to the progression of DR by increasing endothelial shear stress and the release of VEGF that follows stretching of the vessel walls [150]. The EURODIAB Controlled Trial of Lisinopril in Insulin Dependent Diabetes (EUCLID) has shown that the ACE inhibitor lisinopril, significantly reduces the progression of retinopathy in non-hypertensive patients with type-1 diabetes [151]. Other studies using angiotensin II receptor antagonists, have shown that losartan reduces leukocyte entrapment in retinal vessels of rats [152], and candesartan reduces VEGF and retinal abnormalities in diabetic rats [153]. In addition, it was shown that treatment with ACE inhibitors attenuates vitreous levels of VEGF in patients with proliferative DR, probably by interference with a local effect of angiotensin II [154]. These observations suggest that inhibition of the renin-angiotensin system in the eye may have useful effects in the prevention of DR, and some effects may be independent of blood pressure reduction.

\section{FIGHTING INFLAMMATION}

In recent years, DR has been considered a low-grade chronic inflammatory condition. The levels of cytokines, including IL-1 $\beta$, IL-6, and IL-8, are increased in the vitreous of diabetic patients with proliferative DR [155,156], and IL$1 \beta$ levels are increased in the retina of diabetic rats [157]. The expression of different isoforms of nitric oxide synthase, particularly the iNOS, and cycloxigenase- 2 is also increased in diabetes with a subsequent increase in nitric oxide and prostaglandins [157-159]. Increased leukocyte adhesion, ICAM-1 expression, vascular permeability, and capillary occlusion, features commonly found in inflammation, have also been suggested to be involved in the progression of DR [158,160-162].

Leukocytes, including monocytes, neutrophils and some lymphocytes, adhere to the retinal vascular endothelium early in both experimental and human DR [160,163-166]. Further, its occurrence coincides temporally and spatially with the appearance of BRB breakdown, capillary nonperfusion and endothelial cell death [107,163,165]. The expression of adhesion molecules, especially ICAM-1 and VCAM-1, are increased in diabetic retinas and are correlated with leukocyte adhesion [160,164,167,168]. However, a recent study in human subjects has reported that the levels of vascular ICAM-1 are similar in the retinas of control and diabetic subjects, suggesting that other factors might be involved in the increase of leukostasis and capillary occlusion [169]. 
ICAM-1 is a member of the immunoglobulin superfamily of adhesion molecules whose ligands include leukocyte $\beta 2$-integrins CD11a/CD18 and CD11b/CD18. When neutralizing antibodies directed against ICAM-1 are administered into diabetic animals, the leukocyte-related pathology is dramatically reduced [107, 165]. Similarly, when the bioactivity of the ICAM-1 counter receptor CD18 is inhibited, diabetic retinal leukocyte adhesion is potently suppressed [170]. In addition, CD18 and ICAM-1 knockout mice exhibit significantly fewer adherent leukocytes in the retinal vasculature at 11 and 15 months after induction of diabetes with STZ. This condition is associated with fewer damaged endothelial cells and lesser vascular leakage. Also, galactosemia causes pericyte and endothelial cell loss and formation of acellular capillaries, and these changes are significantly reduced in CD18- and ICAM-1-deficient mice [171].

The formation of acellular capillaries and the subsequent retinal ischemia lead to upregulation of VEGF. The injection of VEGF into normal non-diabetic eyes recapitulates many of the retinal vascular changes triggered by diabetes, including leukocyte adhesion, vascular permeability, and capillary non-perfusion [172-175]. VEGF is expressed early in diabetic retinas [176,177], and increases the expression of ICAM-1 and leukocyte adhesion [160]. Also, VEGF upregulation in diabetes correlates with the increased expression of surface integrin and integrin-mediated adhesion [160].

VEGF increases retinal eNOS expression [160] probably by activation of the serine/threonine protein kinase $\mathrm{AKT} / \mathrm{PKB}$, leading to an increase in nitric oxide production and ICAM-1 upregulation [178]. So, the inhibition of endogenous VEGF would lead to the downregulation of retinal ICAM-1 through a reduction in eNOS expression. In fact, retinal nitrite levels were upregulated in diabetic animals and were normalized via the inhibition of endogenous VEGF. Moreover, the inhibition of eNOS via systemic administration of $\mathrm{N}^{\mathrm{G}}$-nitro-L-arginine methyl ester (L-NAME) reduced diabetic-induced leukocyte adhesion [160].

Increased levels of cytokines, such as TNF- $\alpha$ and IL-1 $\beta$, cause cell death and tissue damage. Cytokines induce endothelial cytokine expression and upregulation of adhesion molecules that leads to leukocyte adhesion and endothelial cell death [179]. Recent studies have shown that IL-1 $\beta$ accelerates apoptosis of retinal capillary cells through activation of NF- $\mathrm{KB}$, and the process is exacerbated in highglucose conditions [180].

In diabetes, oxidative stress is increased in the retina and other tissues [181], and it is closely linked to apoptosis in various cells [182]. Reactive oxygen species are considered a strong stimulus for the release of cytokines [183], and IL-1 $\beta$ itself can trigger signaling cascades resulting in excessive production of ROS [184].

Cytokines are attractive targets for the development of novel anti-inflammatory drugs. Soluble TNF- $\alpha$ receptor/Fc construct (TNFR-Fc, etanercept) is used in rheumatoid arthritis [185]. High-dose aspirin and etanercept, each reduced diabetes-induced leukocyte adhesion and suppressed BRB breakdown in diabetic rats [160]. Aspirin decreases
TNF- $\alpha$ retinal levels induced by diabetes, but neither aspirin nor etanercept altered VEGF levels. Aspirin and etanercept also decreased the levels of ICAM-1 induced by diabetes [160].

New strategies for drug development include proteins involved in the synthesis of pro-inflammatory cytokines, such as caspase-1, formerly known as IL-1 $\beta$-converting enzyme (ICE), the enzyme responsible for the production of the pro-inflammatory cytokines IL-1 $\beta$ and IL-18. Results revealed that activation of caspase-1 occurs early in the retina of diabetic mice and diabetic patients [186]. The activation of caspase-1 has been demonstrated in several neurodegenerative diseases, and inhibition of caspase- 1 has been shown to have beneficial effects suppressing these diseases [187,188]. Minocycline, a second-generation chemically modified tetracycline, was able to prevent the activation of capase-1 in the retina of diabetic mice [8]. This compound and others that inhibit caspase-1 could be potential candidates to treat DR.

As mentioned before, glucocorticoids are antiinflammatory drugs. These drugs are currently used in the treatment of many clinical conditions including asthma and rheumatoid arthritis [189]. The anti-inflammatory activity of glucocorticoids is mostly associated with repression of proinflammatory genes such as cytokines, inhibition of proinflammatory transcription factors such as $\mathrm{NF}-\kappa \mathrm{B}$, and induction of apoptosis in leukocytes recruited to the site of inflammation [189]. In addition, in vitro studies showed that triamcinolone, a corticosteroid already in use in clinical trials, downregulates ICAM- 1 expression induced by TNF- $\alpha$ or interferon gamma (IFN- $\gamma$ ) [190].

A large body of evidence shows that inflammation has a key role in the pathology of DR, but only recently, the concept of a low-grade chronic inflammatory disease associated with DR, has been started to be accepted. Therefore, further studies testing the efficacy of antiinflammatory drugs in the prevention and progression of DR are needed. It is important to note that these drugs may be targeted to act at different steps of the inflammatory process.

\section{ASPIRIN: YES OR NO?}

Aggregation of platelets is increased in diabetes, and it had been proposed as the underlying abnormality that triggers capillary occlusion [191]. Platelet microthrombi was shown to occur in retinal capillaries of diabetic patients several decades ago [192]. Some years later, it was observed that patients with rheumatoid arthritis receiving high doses of aspirin tended to have less severe DR [193]. Indeed, large thrombi occur more often in retinas from diabetic patients than in control retinas [194]. Recently, Kern and Engerman found that treatment of diabetic dogs with aspirin reduced the number of acellular capillaries and retinal hemorrhages after five years of diabetes [195].

Platelets by themselves are no longer thought to be of prime importance in blocking retinal capillaries. Changes in endothelial cells and leukocytes are also believed to be responsible for capillary occlusion (for review see [163]). Experiments with diabetic rats showed that high dose aspirin reduces leukocyte adhesion to diabetic retinal capillaries, arterioles and venules [16]. Aspirin also reduced the 
expression of integrins on surface of leukocytes and the adhesion molecule, ICAM-1, in the capillary wall. Other effects included reduction of eNOS levels and less production of TNF- $\alpha$. Taking this into account, there seems to be ample reason for using aspirin in DR.

The effectiveness of aspirin in clinical trials has been controversial. The statistically significant inhibitory effect of the drug on retinopathy in one clinical trial [196] was shown, but this study was not considered to be clinically important, since there was only a slight beneficial effect. In contrast, in a larger clinical trial, aspirin had no significant beneficial effects [197]. However, in view recently published literature, this view may have to be reconsidered, and high dose aspirin may become one of the possible additions to preventive treatment of DR.

\section{WILL BE ANTIHISTAMINES USEFUL IN DR?}

As with VEGF, histamine is considered to be a permeabilizing factor, and acts on cells through four types of receptors, $\mathrm{H} 1, \mathrm{H} 2, \mathrm{H} 3$ and $\mathrm{H} 4$. Histamine has been implicated in BRB dysfunction in both experimental diabetes and diabetic patients [198-200]. The synthesis of histamine is increased in the retinas of diabetic rats [201,202], and the mRNA levels of histidine decarboxylase, the enzyme responsible for histamine synthesis, are increased in retinal neurons and glia [203]. These data suggest the involvement of neural cells in diabetes-induced vascular leakage, possibly mediated by histamine. Inhibition of histidine decarboxylase decreases histamine overproduction induced by diabetes, and similar effects were observed with insulin administration in experimental diabetes, indicating that insulin modulates histamine metabolism [201]. Also, drugs blocking histamine receptors, such as diphenhydramine- $\mathrm{HCl}$, ranitidine and astemizole, have been shown to reduce the leakage of retinal vessels in diabetic rats and humans [200,202].

Some evidences suggest that histamine increases the permeability of BRB because it downregulates the expression of tight junction proteins, particularly ZO-1 expression [204]. Studies exploring the involvement of histamine on the permeability of BRB are not abundant, but it has also been shown that blocking histamine receptors attenuates blood-brain barrier permeability and ameliorates cerebral blood flow disturbances [205]. It is therefore important to clarify the role of histamine on the breakdown of BRB, since it might be another tool used against DR.

\section{DIABETIC RETINOPATHY: TREATING NEURODEGENERATIVE DISEASE?}

A

Despite being usually considered a vascular disease, recent evidence suggests that DR may also be a neurodegenerative disorder [4,5]. Retinal neurons comprise photoreceptors, bipolar cells, amacrine cells, horizontal cells and ganglion cells. Photoreceptors receive light and transduce photons into electrical impulses, which converge ultimately on ganglion cells to transmit signals to the brain. Therefore, vision loss must result from impaired neuronal function. In fact, loss of color sensitivity [206,207] and contrast sensitivity [208] has been reported as early symptoms of neuronal dysfunction of the retina, occurring within 2 years after the onset of DR in humans.

Recent reports demonstrate that diabetes affects retinal neurons, probably prior to vascular changes. Neuronal cell loss occurs by apoptosis in both diabetic animals and diabetic patients with a concomitant decrease in the thickness of the inner retina [209]. Several other reports showed that neurodegeneration occurs in the diabetic retina, both in animal models and in humans [210-212]. Recently, it was reported that when the RTP801 gene (previously isolated as a hypoxia-inducible factor, HIF-1) was knocked out in an animal model of retinopathy of prematurity, neuronal death and neovascularization were attenuated, indicating that RTP801 gene may be a novel therapeutic target for treatment of retinopathy of prematurity and DR [213].

\section{Managing the Glutamatergic System in the Retina}

Glutamate is the most important excitatory amino acid in the retina [214], but overactivation of ionotropic glutamate receptors can lead to cell death [215]. Glutamate is implicated in several neurodegenerative diseases in the Central Nervous System, including the retina, such as retinitis pigmentosa and glaucoma [216,217]. The role that glutamate plays in DR is still poorly understood, but several reports have demonstrated that the glutamate concentration increases in diabetic rat retinas [117,218]. Glutamate concentrations in the vitreous of diabetic patients and animals are also increased [219-221], probably due to an increase in the release of glutamate.

Under normal conditions, glutamate is kept in low concentrations mainly due to a glial-specific enzyme, glutamine synthetase (GS), which has a neuroprotector role against retinal injury due to excessive glutamate [222]. In diabetic rats, GS activity and content are decreased [223], and glutamate uptake is decreased as well [224], which may be related to glial changes occurring within the diabetic retina. These changes can lead to excitotoxic levels of glutamate in the retina, which may be responsible for changes in retinal neurotransmission and vision loss.

Therapies using glutamate receptor antagonists, such as memantine, an uncompetitive NMDA-receptor antagonist, have been shown to be of great value in some neurological disorders such as Alzheimer's disease. The results of a phase III clinical study reported that memantine $(20 \mathrm{mg} /$ day $)$ had a notable tolerability among patients and it was found to be efficacious for moderate to severe Alzheimer's disease [225]. In fact, it was already reported that memantine was able to reduce NMDA-induced increase in nitric oxide and TBARS in rat retinas [117], indicating that memantine or similar compounds could be used to prevent increased oxidative stress induced by elevated glutamate [117]. In another retinal model, memantine was partially protective against glutamate excitotoxicity for retinal ganglion cells [226].

NitroMemantines are second-generation memantine derivatives, designed to have enhanced neuroprotective efficacy without sacrificing safety, by using the memantine binding site for the targeted delivery of nitric oxide to a second modulatory site on the NMDA receptor [227]. It was already observed that patients taking nitroglycerin for other 
medical purposes may be resistant to glaucomatous visual field loss [228], but further studies need to be performed to investigate the potential of these drugs in the prevention of DR.

\section{INSULIN AS A TROPHIC FACTOR}

Recent evidences show that both vascular and neural retinal cells express insulin receptors (IR) (for review see [229]). Insulin action begins when ligand binds the receptor on $\alpha$ subunits, which induces conformational changes and activates the intrinsic tyrosine kinase activity in the $\beta$ subunits in the cytoplasm. The IR autophosphorylates on tyrosine residues within its tyrosine kinase domain and initiates a cascade of phosphorylation-dephosphorylation, and translocation events within the cell.

In bovine retina, IR were found in all retinal layers, predominantly located on the dendritic processes of neurons and in Müller cells [230]. Because the retina expresses the IR at similar levels to other classically responsiveness organs, it must be considered a major target for insulin action. Insulin has a protective role in the retina, since it was reported that in the absence of insulin, there is an increase in ganglion cell apoptosis [231], and cell death is reduced in the presence of insulin in developing chick retinas [232]. In diabetic rats, insulin can rescue retinal neurons from apoptosis by reducing caspase-3 enzyme activity [233].

The therapeutic action of insulin in DR is still controversial. Some clinical studies demonstrated that intensive insulin therapy might cause a transient worsening of retinopathy in some individuals [234-236]. It was also reported that knockout mice for a vascular endothelial cell specific insulin receptor were protected from retinal neovascularization [237]. Recently, Poulaki et al. [105] found that subcutaneous insulin implants, delivering lowdose (2 units) of insulin daily, increased blood-retinal barrier permeability and VEGF expression in rats with shortterm streptozotocin diabetes.

On the other hand, the study by The Diabetes Control and Complications Trial/Epidemiology of Diabetes Interventions and Complications Research Group reported that intensive insulin treatment of type 1 diabetes patients reduced the risk of progression of retinopathy and nephropathy [238]. The same study also concludes that intensive insulin therapy adopted early in the course of early onset diabetes appears to have a protective effect that lasts for many years, and is superior to the adoption of intensive therapy later in the course of the disease. However, more experiments must be performed and if so, systemically administered insulin may be a direct pharmacological intervention for the retina and other tissues, including the kidneys and peripheral nerves. After understanding the importance of insulin action, new drugs may be developed to enhance the actions of insulin and IR.

\section{PROTECTING NEURONS WITH NEUROTROPHINS}

The neurotrophin family of ligands contains nerve growth factor (NGF), brain-derived neurotrophic factor (BDNF), neurotrophin-3, and neurotrophin-4/5. Neurotrophins and their receptors, TrkA, TrkB and TrkC, are expressed primarily in neurons. Neurotrophic factors use a variety of signal transduction systems, involving primarily the intrinsic kinase activity of the Trk receptors, leading to activation of various serine-threonine kinases [239].

Neurotrophic factors have the potential to provide new therapies for neurodegenerative diseases such as Alzheimer's disease, Parkinson's disease, peripheral neuropathy, and optic neuropathy. Neurotrophins are known to have survival and neurite outgrowth-promoting activity in the central and peripheral nervous systems [240]. Neuronal components of the retina contains receptors for the different neurotrophins, and they can prevent the loss of ganglion cells after retinal injury [241,242]. BDNF levels are decreased in the retina of diabetic animals, and intraocular administration of BDNF rescued dopaminergic amacrine cells from neurodegeneration [243], demonstrating its therapeutical potential. However, a clinical trial performed in patients with diabetic neuropathy, in which BDNF was injected subcutaneously, failed to demonstrate a significant beneficial effect in nerve conduction [244]. Further studies will be necessary to better understand the role of neurotrophins in the retina, and possibly to use them as neuroprotective agents.

\section{CONCLUDING REMARKS}

It is important to emphasize that the potential damage caused by elevated glucose on retinal function is not a consequence of an isolated factor or pathway, but it is the sum of various mechanisms (Fig. 1), and a consequence of multiple interactions between different molecules and pathways. The strategies designed to prevent, treat or ease the symptoms of DR must take this into account. Probably, the best way to deal with DR is using a multidrug therapy, and not using only a single drug. Figure 1 summarizes current knowledge about DR, that is, processes and molecules considered to be involved in the pathogenesis of DR. Pharmacological tools that have been used to prevent or restore retinal dysfunction are also indicated.

In recent years, important advances were achieved in order to clarify the pathogenesis of DR, but the puzzle is far from being completed. Genetic differences between patients might also complicate this unsolved problem. In any event, new strategies and new drugs are being tested in experimental models, and in some cases, the results obtained are promising. In the past, several promising drugs did not prove to be effective in humans, and therefore, we must keep developing and characterizing new pharmacological tools effective in the treatment of DR.

\section{ACKNOWLEDGEMENTS}

The authors acknowledge financial support from Foundation for Science and Technology (FCT), Portugal, and FEDER. The authors also thank to Aurea Castilho and Célia Aveleira, who helped in text and figure editing.

\section{ABBREVIATIONS \\ $\mathrm{ACE}=$ Angiotensin converting enzyme \\ AGEs = Advanced glycation end products}




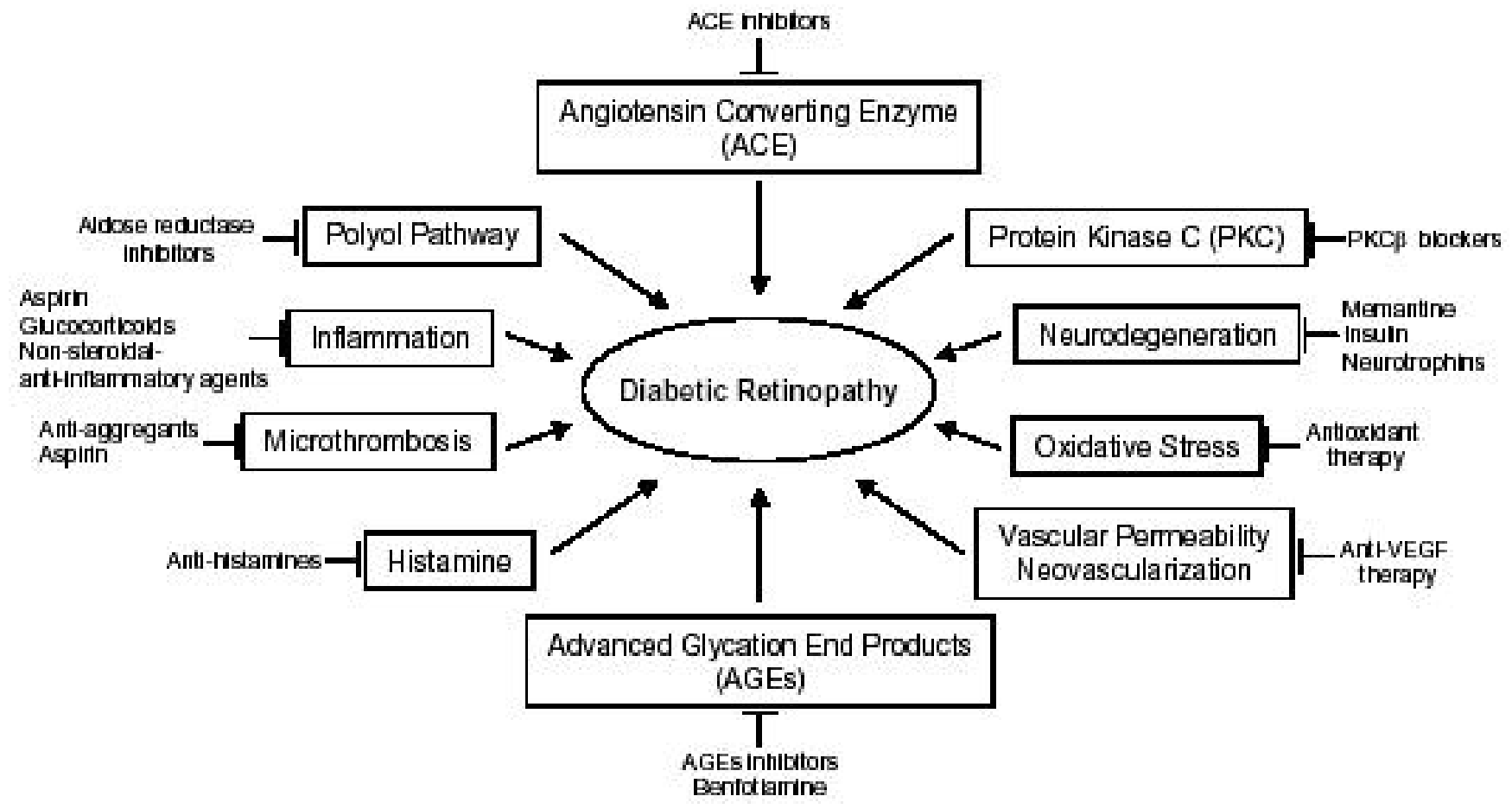

Fig. (1). Processes and molecules involved in the pathogenesis of DR as potential drug targets. Pharmacological tools with possible application in the therapy of DR.

$\begin{array}{ll}\mathrm{AR} & =\text { Aldose reductase } \\ \mathrm{ARIs} & =\text { AR inhibitors } \\ \mathrm{BDNF} & =\text { Brain-derived neurotrophic factor } \\ \mathrm{BRB} & =\text { Blood-retinal barrier } \\ \mathrm{BRECs} & =\text { Bovine retinal endothelial cells } \\ \mathrm{CD} & =\text { Calcium dobesilate } \\ \mathrm{COX}-2 & =\text { Cyclooxygenase } 2 \\ \mathrm{DAG} & =\text { Diacylglycerol } \\ \mathrm{DAG}-\mathrm{PKC} & =\text { Diacylglycerol-protein kinase C } \\ \mathrm{DR} & =\text { Diabetic Retinopathy } \\ \mathrm{eNOS} & =\text { Endothelial nitric oxide synthase } \\ \mathrm{EUCLID} & =\text { EURODIAB Controlled Trial of Lisinopril } \\ \mathrm{GS} & =\text { in Insulin-Dependent Diabetes } \\ \mathrm{HUVECs} & =\text { Human umbilical vein endothelial cells } \\ \mathrm{ICAM-1} & =\text { Intracellular adhesion molecule } 1 \\ \mathrm{ICE} & =\text { IL-1 } \beta \text {-converting enzyme } \\ \mathrm{IGF}-1 & =\text { Insulin-like growth factor } \\ \mathrm{IFN- \gamma} & =\text { Interferon gamma } \\ \mathrm{IL} & =\text { Interleukin } \\ \mathrm{IL}-1 \beta & =\text { Interleukin-1 beta } \\ \mathrm{L}-\mathrm{NAME} & =\text { NG-nitro-L-arginine methyl ester } \\ \mathrm{iNOS} & =\text { Inducible nitric oxide synthase } \\ \mathrm{IR} & =\text { Insulin receptors }\end{array}$

$$
\begin{array}{ll}
\text { JAM } & =\text { Junctional adhesion molecule } \\
\text { NF- } \mathrm{B} B & =\text { Nuclear factor kappa } \mathrm{B} \\
\text { NGF } & =\text { Nerve growth factor } \\
\text { NMDA } & =\text { N-methyl-D-aspartate } \\
\text { nNOS } & =\text { Neuronal nitric oxide synthase } \\
\text { PDGF } & =\text { Platelet derived growth factor } \\
\text { PKC } & =\text { Protein kinase } \mathrm{C} \\
\text { PKC } \beta & =\text { PKC beta isoform } \\
\text { RAS } & =\text { Renin-angiotensin system } \\
\text { ROS } & =\text { Reactive oxygen species } \\
\text { SOD } & =\text { Superoxide dismutase } \\
\text { TBARS } & =\text { Thiobarbituric acid-reacting substances } \\
\text { TGF- } \alpha & =\text { Transforming growth factor alpha } \\
\text { TNF- } \alpha & =\text { Tumor necrosis factor alpha } \\
\text { TNFR-Fc } & =\text { TNF- } \alpha \text { receptor/Fc construct } \\
\text { VCAM-1 } & =\text { Vascular cell adhesion molecule } 1 \\
\text { VEGF } & =\text { Vascular endothelial growth factor } \\
\text { VEGF-R1 } & =\text { VEGF receptor } 1 \\
\text { VEGF-R2 } & =\text { VEGF receptor } 2 \\
\text { ZO } & =\text { Zonula occludens }
\end{array}
$$

\section{REFERENCES}

[1] Amos, A.F.; McCarty, D.J.; Zimmet, P.Diabet. Med., 1997, 14, 1.

[2] Cunha-Vaz, J.G. Ophthalmologica, 2000, 214, 377. 
[3] Aiello, L.P.; Gardner, T.W.; King, G.L.; Blankenship, G.; Cavallerano, J.D.; Ferris, F.L. $3^{\text {rd }}$; Klein, R. Diabet. Care, 1998, 21,143 .

[4] Gardner, T.W.; Antonetti, D.A.; Barber, A.J.; LaNoue, K.F.; Levison, S.W. Surv. Ophthalmol., 2002, 47, 253.

[5] Barber, A.J. Prog. Neuropsychopharmacol. Biol. Psychiatry, 2003, 27, 283.

[6] Lorenzi, M.; Gerhardinger, C. Diabetologia, 2001, 44, 791.

[7] De La Cruz, J.P.; Gonzalez-Correa, J.A.; Guerrero, A.; De La Cuesta, F.S. Diabet. Metab. Res. Rev., 2004, 20, 91.

[8] Mohr, S. Expert. Opin. Investig. Drugs, 2004, 13, 189.

[9] Gardner, T.W.; Antonetti, D.A.; Barber, A.J.; Lieth, E.; Tarbell, J.A. Doc. Ophthalmol., 1999, 229.

[10] Wittchen, E.S.; Haskins, J.; Stevenson, B.R. J. Biol. Chem., 1999, 274,35179 .

[11] Fanning, A.S.; Ma, T.Y.; Anderson, J.M. FASEB J., 2002, 16, 1835.

[12] Vitale, S.; Maguire, M.G.; Murphy, R.P.; Hiner, C.J.; Rourke, L.; Sackett, C.; Patz A. Ophthalmology, 1995, 102, 1170.

[13] Caldwell, R.B.; Bartoli, M.; Behzadian, M.A.; El-Remessy, A.E.; Al-Shabrawey, M.; Platt, D.H.; Caldwell, R.W. Diabetes Metab. Res. Rev., 2003, 19, 442 .

[14] Gardner, T.W.; Lesher, T.; Khin, S.; Vu, C.; Barber, A.J.; Brennan, W.A. Jr. Biochem. J., 1996, 320, 717.

[15] Armstrong, D.; Ueda, T.; Ueda, T.; Aljada, A.; Browne, R.; Fukuda, S.; Spengler, R.; Chou, R.; Hartnett, M.; Buch, P.; Dandona, P.; Sasisekharan, R.; Dorey, C.K. Angiogenesis, 1998, 2, 93.

[16] Joussen, A.M.; Poulaki, V.; Mitsiades, N.; Kirchhof, B.; Koizumi, K.; Dohmen, S.; Adamis, A.P. FASEB J., 2002, 16, 438.

[17] Mathews, M.K.; Merges, C.; McLeod, D.S.; Lutty, G.A. Invest. Ophthalmol. Vis. Sci., 1997, 38, 2729.

[18] Hammes, H.P.; Lin, J.; Bretzel, R.G.; Brownlee, M.; Breier, G. Diabetes, 1998, 47, 401 .

[19] Qaum, T.; Xu, Q.; Joussen, A.M.; Clemens, M.W.; Qin, W.; Miyamoto, K.; Hassessian, H.; Wiegand, S.J.; Rudge, J.; Yancopoulos, G.D.; Adamis, A.P. Invest. Ophthalmol. Vis. Sci., $200142,2408$.

[20] Aiello, L.P.; Avery, R.L.; Arrigg, P.G.; Keyt, B.A.; Jampel, H.D.; Shah, S.T.; Pasquale, L.R.; Thieme, H.; Iwamoto, M.A.; Park, J.E. Nguyen, H.V.; Aiello, L.M.; Ferrara, N., King, G.L. N. Engl. J. Med., 1994, 1331, 1480.

[21] Saishin, Y.; Saishin, Y.; Takahashi, K.; Lima e Silva, R.; Hylton, D.; Rudge, J.S.; Wiegand, S.J.; Campochiaro, P.A. J. Cell Physiol., 2003, 195, 241.

[22] Pertovaara, L., Kaipainen, A.; Mustonen, T.; Orpana, A.; Ferrara, N.; Saksela, O.; Alitalo, K. J. Biol. Chem., 1994, 269, 6271.

[23] Li, J.; Perrella, M.A.; Tsai, J.C.; Yet, S.F.; Hsieh, C.M.; Yoshizumi, M.; Patterson, C.; Endege, W.O.; Zhou, F.; Lee, M.E. J. Biol. Chem., 1995, 270, 308.

[24] Cohen, T.; Nahari, D.; Cerem, L.W.; Neufeld, G.; Levi, B.Z. J. Biol. Chem., 1996, 271, 736.

[25] Goad, D.L.; Rubin, J.; Wang, H.; Tashjian, A.H. Jr.; Patterson, C. Endocrinology, 1996, 137, 2262.

[26] Ryuto, M.; Ono, M.; Izumi, H.; Yoshida, S.; Weich, H.A.; Kohno, K., Kuwano, M. J. Biol. Chem., 1996, 271, 28220.

[27] Hoffmann, S.; Friedrichs, U.; Eichler, W.; Rosenthal, A.; Wiedemann, P. Graefes Arch. Clin. Exp. Ophthalmol., 2002, 240, 996.

[28] Robinson, C.J.; Stringer, S.E. J. Cell Sci., 2001, 114, 853.

[29] Duh, E.; Aiello, L.P. Diabetes, 1999, 48, 1899.

[30] Antonetti, D.; Barber, A.; Hollinger, L.; Wolpert, E.; Gardner, T. J. Biol. Chem., 1999, 274, 23463.

[31] Wang, W.; Dentler, W.L.; Borchardt, R.T. Am. J. Physiol. Heart Circ. Physiol., 2001, 280, 434.

[32] Takeda, M.; Mori, F.; Yoshida, A.; Takamiya, A.; Nakagomi, S.; Sato, E.; Kiyama, H. Diabetologia, 2001, 44, 1043.

[33] El-Remessy, A.B.; Behzadian, M.A.; Abou-Mohamed, G.; Franklin, T.; Caldwell, R.W.; Caldwell, R.B. Am. J. Pathol., 2003, 162, 1995.

[34] Carmo, A.; Cunha-Vaz, J.G.; Carvalho, A.P.; Lopes, M.C. Mediators Inflamm., 2000, 9, 243.

[35] Khan, Z.A.; Chakrabarti, S. Exp. Diabesity Res., 2003, 4, 287.

[36] Hamanaka, T.; Akabane, N.; Yajima, T.; Takahashi, T.; Tanabe, A. Am. J. Ophthalmol., 2001, 132, 648.
[37] Hofman, P.; Van Blijswijk, B.C.; Gaillard, P.J.; Vrensen, G.F.; Schlingemann, R.O. Arch. Ophthalmol., 2001, 119, 861.

[38] Shima, D.T.; Adamis, A.P.; Ferrara, N.; Yeo, K.T.; Yeo, T.K.; Allende, R.; Folkman, J.; D'Amore, P.A. Mol. Med., 1995, 1, 182.

[39] Ferrara, N.; Gerber, H.P. Acta Haematol., 2001, 106, 148.

[40] Okamoto, N.; Tobe, T.; Hackett, S.F.; Ozaki, H.; Vinores, M.A.; LaRochelle, W.; Zack, D.J.; Campochiaro, P.A. Am. J. Pathol., 1997, 151, 281.

[41] Seo, M.S.; Kwak, N.; Ozaki, H.; Yamada, H.; Okamoto, N.; Yamada, E.; Fabbro, D.; Hofmann, F.; Wood, J.M.; Campochiaro, P.A. Am. J. Pathol., 1999, 154, 1743.

[42] Ozaki, H.; Seo, M.S.; Ozaki, K.; Yamada, H.; Yamada, E.; Okamoto, N.; Hofmann, F.; Wood, J.M.; Campochiaro, P.A. Am. J. Pathol., 2000, 156, 697.

[43] Krzystolik, M.G.; Afshari, M.A; Adamis, A.P.; Gaudreault, J.; Gragoudas, E.S.; Michaud, N.A.; Li, W.; Connolly, E.; O'Neill, C.A.; Miller, J.W. Arch. Ophthalmol., 2002, 120, 338.

[44] The EyeTech Study Group. Retina, 2002, 22, 143.

[45] Kwak, N.; Okamoto, N.; Wood, J.M.; Campochiaro, P.A. Invest. Ophthalmol. Vis. Sci., 2000, 41, 3158.

[46] Bainbridge, J.W.; Mistry, A.; De Alwis, M.; Paleolog, E.; Baker, A.; Thrasher, A.J.; Ali, R.R. Gene Ther., 2002, 9, 320.

[47] Lai, Y.K.; Shen, W.Y.; Brankov, M.; Lai, C.M.; Constable, I.J.; Rakoczy, P.E. Gene Ther., 2002, 9, 804.

[48] Unsoeld, A.S.; Junker, B.; Mazitschek, R., Martin. G.; Hansen, L.L.; Giannis, A.; Agostini, H.T. Mol. Vis., 2004, 10, 468.

[49] Maier, P.; Unsoeld, A.S.; Junker, B.; Martin, G.; Drevs, J.; Hansen, L.L.; Agostini, H.T. Graefes Arch. Clin. Exp. Ophthalmol., 2005, [Epub ahead of print]

[50] Nauck, M.; Karakiulakis, G.; Perruchoud, A.; Papakonstantinou, E.; Roth, M. Eur. J. Pharmacol., 1998, 341, 309.

[51] Brooks, H.L. Jr.; Caballero, S. Jr.; Newell, C.K.; Steinmetz, R.L.; Watson, D.; Segal, M.S.; Harrison, J.K.; Scott, E.W.; Grant, M.B. Arch. Ophthalmol., 2004, 122, 1801.

[52] Antonetti, D.A.; Wolpert, E.B.; DeMaio, L.; Harhaj, N.S.; Scaduto, R.C. Jr. J. Neurochem., 2002, 80, 667.

[53] Romero, I.A.; Radewicz, K.; Jubin, E.; Michel, C.C.; Greenwood, J.; Couraud, P.O.; Adamson, P. Neurosci. Lett., 2003, 344, 112.

[54] Van den Enden, M.K.; Nyengaard, J.R.; Ostrow, E.; Burgan, J.H.; Williamson, J.R. Invest. Ophthalmol. Vis. Sci., 1995, 36, 1675.

[55] Pugliese, G.; Tilton, R.G.; Williamson, J.R. Diabetes Metab. Rev., 1991, 7, 35.

[56] Williamson, J.R.; Chang, K.; Frangos, M.; Hasan, K.S.; Ido, Y.; Kawamura, T.; Nyengaard, J.R.; van den Enden, M.; Kilo, C.; Tilton, R.G. Diabetes, 1993, 42, 801.

[57] Demaine, A.; Cross, D.; Millward, A. Invest. Ophthalmol. Vis. Sci., 2000, 41, 4064.

[58] Robison, W.G.Jr. Adv. Exp. Med. Biol., 1988, 246, 365.

[59] Kato, N.; Mizuno, K.; Makino, M.; Suzuki, T.; Yagihashi, S. Diabet. Res. Clin. Pract., 2000, 50, 77.

[60] Sorbinil Retinopathy Trial Research Group. Arch. Ophthalmol., 1990, 108, 1234.

[61] Fagius, J.; Brattberg, A.; Jameson, S.; Berne, C. Diabetologia, $\mathbf{1 9 8 5}, 28,323$.

[62] Yagihashi, S.; Kamijo, M.; Ido, Y.; Mirrlees, D.J. Diabetes, 1990, 39,690 .

[63] Judzewitsch, R.G.; Jaspan, J.B.; Polonsky, K.S.; Weinberg, C.R ; Halter, J.B.; Halar, E., Pfeifer, M.A.; Vukadinovic, C.; Bernstein, L.; Schneider, M.; Liang, K.Y.; Gabbay, K.H.; Rubenstein, A.H.; Porte, D. Jr. N. Engl. J. Med., 1983, 308, 119.

[64] Christensen, J.E.; Varnek, L.; Gregersen, G. Acta Neurol. Scand., 1985, 71, 164 .

[65] O'Hare, J.P.; Morgan, M.H.; Alden, P.; Chissel, S.; O'Brien, I.A.; Corrall, R.J. Diabet. Med., 1988, 5, 537.

[66] Monnier, V.M.; Elmets, C.A.; Frank, K.E.; Vishwanath, V.; Yamashita, T. J. Clin. Invest., 1986, 78, 832.

[67] Bucala, R.; Cerami, A. Adv. Pharmacol.,1992, 23, 1.

[68] Giardino, I.; Edelstein, D.; Brownlee, M. J. Clin. Invest., 1994, 94, 110.

[69] Abdel-Wahab, Y.H.; O'Harte, F.P.; Ratcliff, H.; McClenaghan, N.H.; Barnett, C.R.; Flatt, P.R. Diabetes, 1996, 45, 1489.

[70] Paget, C.; Lecomte, M.; Ruggiero, D.; Wiernsperger, N.; Lagarde, M. Free Radic. Biol. Med., 1998, 25, 121.

[71] Mohamed, A.K.; Bierhaus, A.; Schiekofer, S.; Tritschler, H.; Ziegler, R.; Nawroth, P.P. Biofactors 1999, 10, 167.

[72] Vlassara, H.; Bucala, R.; Striker, L. Lab. Invest., 1994, 70, 138. 
[73] Chibber, R.; Molinatti, P.A.; Rosatto, N.; Lambourne, B.; Kohner, E.M. Diabetologia, 1997, 40, 156.

[74] Nakamura, N.; Hasegawa, G.; Obayashi, H.; Yamazaki, M Ogata, M.; Nakano, K.; Yoshikawa, T.; Watanabe, A.; Kinoshita S.; Fujinami, A.; Ohta, M.; Imamura, Y.; Ikeda, T. Diabet. Res. Clin. Pract., 2003, 61, 93.

[75] Karachalias, N.; Babaei-Jadidi, R.; Ahmed, N.; Thornalley, P.J. Biochem. Soc. Trans., 2003, 31, 1423.

[76] Hammes, H.P.; Alt, A.; Niwa, T.; Clausen, J.T.; Bretzel, R.G.; Brownlee, M.; Schleicher, E.D. Diabetologia, 1999, 42, 728

[77] Denis, U.; Lecomte, M.; Paget, C.; Ruggiero, D.; Wiernsperger, N.; Lagarde, M. Free Radic. Biol. Med., 2002, 33, 236.

[78] Hammes, H.P.; Martin, S.; Federlin, K.; Geisen, K.; Brownlee, M. Proc. Natl. Acad. Sci. USA, 1991, 88, 11555.

[79] Hammes, H.P.; Brownlee, M.; Edelstein, D.; Saleck, M.; Martin, S.; Federlin, K. Diabetologia, 1994, 37, 32.

[80] Hammes, H.P.; Ali, S.S.; Uhlmann, M.; Weiss, A.; Federlin, K. Geisen, K., Brownlee, M. Diabetologia, 1995, 38, 269.

[81] Hammes, H.P.; Strodter, D.; Weiss, A.; Bretzel, R.G.; Federlin, K Brownlee, M. Diabetologia, 1995, 38, 656.

[82] Roufail, E.; Soulis, T.; Boel, E.; Cooper, M.E.; Rees, S. Diabetologia, 1998, 41, 1419.

[83] Gardiner, T.A.; Anderson, H.R.; Stitt, A.W. J. Pathol., 2003, 201, 328.

[84] Vasan, S.; Foiles, P.G.; Founds, H.W. Expert. Opin. Investig. Drugs, 2001, 10, 1977.

[85] Do Carmo, A.; Lopes, C.; Santos, M.; Proença, R.; Cunha-Vaz, J.; Carvalho, A.P. Gen. Pharmacol., 1998, 30, 319.

[86] Nilsson, B.O. Inflamm. Res., 1999, 48, 509.

[87] Vasan, S.; Zhang, X.; Zhang, X.; Kapurniotu, A.; Bernhagen, J. Teichberg, S.; Basgen, J.; Wagle, D.; Shih, D.; Terlecky, I.; Bucala, R.; Cerami, A.; Egan, J.; Ulrich, P. Nature, 1996, 382, 275.

[88] Wolffenbuttel, B.H.; Boulanger, C.M.; Crijns, F.R.; Huijberts, M.S.; Poitevin, P.; Swennen, G.N.; Vasan, S.; Egan, J.J.; Ulrich, P.; Cerami, A.; Levy, B.I. Proc. Natl. Acad. Sci. USA, 1998, 95, 4630.

[89] Cooper, M.E.; Thallas, V.; Forbes, J.; Scalbert, E.; Sastra, S.; Darby, I.; Soulis, T. Diabetologia, 2000, 43, 660.

[90] Asif, M.; Egan, J.; Vasan, S.; Jyothirmayi, G.N.; Masurekar, M.R.; Lopez, S.; Williams, C.; Torres, R.L.; Wagle, D.; Ulrich, P.; Cerami, A.; Brines, M.; Regan, T.J. Proc. Natl. Acad. Sci. USA, 2000, 97, 2809.

[91] Bitsch, R.; Wolf, M.; Moller, J.; Heuzeroth, L.; Gruneklee, D. Ann. Nutr. Metab., 1991, 35, 292.

[92] Loew, D. Int. J. Clin. Pharmacol. Ther., 1996, 34, 47.

[93] Babaei-Jadidi, R.; Karachalias, N.; Ahmed, N.; Battah, S.; Thornalley, P.J. Diabetes, 2003, 52, 2110.

[94] Stracke, H.; Lindemann, A.; Federlin, K. Exp. Clin. Endocrinol. Diabetes, 1996, 104, 311.

[95] Beltramo, E.; Berrone, E.; Buttiglieri, S.; Porta, M. Diabetes Metab. Res. Rev., 2004, 20, 330.

[96] Hammes, H.P.; Du, X.; Edelstein, D.; Taguchi, T.; Matsumura, T.; Ju, Q.; Lin, J.; Bierhaus, A.; Nawroth, P.; Hannak, D.; Neumaier, M.; Bergfeld, R.; Giardino, I.; Brownlee, M. Nat. Med., 2003, 9, 294.

[97] Shiba, T.; Inoguchi, T.; Sportsman, R.J.; Heath, W.F.; Bursell, S.E.; King, G.L. Am. J. Physiol., 1993, 28, E783.

[98] Ishii, H.; Jirousek, M.R.; Koya, D.; Takagi, C.; Xia, P.; Clermont, A.; Bursell, S.E.; Kern, T.S.; Ballas, L.M.; Heath, W.F.; Stramm, L.E.; Feener, E.P.; King, G.L. Science, 1996, 272, 728

[99] Koya, D.; King, G.L. Diabetes, 1998, 47, 859.

[100] Idris, I.; Gray, S.; Donnelly, R. Diabetologia, 2001, 44, 659.

[101] Park, J.Y.; Takahara, N.; Gabriele, A.; Chou, E.; Naruse, K.; Suzuma, K.; Yamauchi, T.; Ha, S.W.; Meier, M.; Rhodes, C.J.; King, G.L. Diabetes, 2000, 49, 1239.

[102] Frank, R.N. Am. J. Ophthalmol., 2002, 133, 693.

[103] Aiello, L.P.; Bursell, S.E.; Clermont, A.; Duh, E.; Ishii, H.; Takagi, C.; Mori, F.; Ciulla, T.A.; Ways, K.; Jirousek, M.; Smith, L.E.H.; King, G.L. Diabetes, 1997, 46, 1473.

[104] Williams, B.; Gallacher, B.; Patel, H.; Orme, C. Diabetes, 1997, 46, 1497

[105] Poulaki, V.; Qin, W.Y.; Joussen, A.M.; Hurlbut, P.; Wiegand, S.J.; Rudge, J.; Yancopoulos, G.D.; Adamis, A.P. J. Clin. Invest., 2002, $109,805$.

[106] Xu, Q.W.; Qaum, T.; Adamis, A.P. Invest. Ophthalmol. Vis. Sci., 2001, 42, 789 .
[107] Miyamoto, K.; Khosrof, S.; Bursell, S-E.; Rohan, R.; Murata, T.; Clermont, A.; Aiello, L.P.; Ogura, Y.; Adamis, A.P. Proc. Natl. Acad. Sci. USA, 1999, 96, 10836.

[108] Lane, T.A.; Lamkin, G.E.; Wancewicz, E. Biochem. Biophys. Res. Commun., 1989, 161, 945.

[109] Deisher, T.A.; Haddix, T.L.; Montgomery, K.F.; Pohlman, T.H.; Kaushansky, K.; Harlan, J.M. FEBS Lett., 1993, 331, 285.

[110] Morigi, M.; Angioletti, S.; Imberti, B. Donadelli, R.; Micheletti, G.; Figlivzzi, M.; Remuzzi, A.; Zoja, C.; Remuzzi, G. J. Clin. Invest., 1998, 101, 1905 .

[111] Nonaka, A.; Kiryu, J.; Tsujikawa, A.; Yamashiro, K.; Miyamoto, K.; Nishiwaki, H.; Honda, Y.; Ogura, Y. Invest. Ophthalmol. Vis. Sci., 2000, 41, 2702.

[112] Milton, R.C.; Aiello, L.P.; Davis, M.D. Diabetes, 2003, E-abstract, 544-P.

[113] Doly, M.; Droy-Lefaix, M.T.; Braquet, P. EXS, 1992, 62, 299.

[114] Kowluru, R.A. Acta Diabetol., 2001, 38, 179

[115] Hartnett, M.E.; Stratton, R.D.; Browne, R.W.; Rosner, B.A.; Lanham, R.J.; Armstrong, D. Diabet.. Care, 2000, 23, 234.

[116] Kowluru, R.A.; Engerman, R.L.; Kern, T.S. Curr. Eye Res., 2000 21,814 .

[117] Kowluru, R.A.; Engerman, R.L.; Case, G.L.; Kern, T.S. Neurochem. Int., 2001, 38, 385.

[118] Du, Y.; Miller, C.M.; Kern, T.S. Free Radic. Biol. Med., 2003, 35, 1491.

[119] Obrosova, I.G.; Minchenko, A.G.; Marinescu, V.; Fathallah, L.; Kennedy, A.; Stockert, C.M.; Frank, R.N.; Stevens, M.J. Diabetologia, 2001, 44, 1102.

[120] Obrosova, I.G.; Minchenko, A.G.; Vasupuram, R.; White, L.; Abatan, O.I.; Kumagai, A.K.; Frank, R.N.; Stevens, M.J. Diabetes, 2003, 52, 864.

[121] Kowluru, R.A.; Koppolu, P. Free Radic. Res., 2002, 36, 993

[122] Kowluru, R.A.; Odenbach, S. Diabetes, 2004, 53, 3233

[123] Ansari, N.H.; Zhang, W.; Fulep, E.; Mansour, A. J. Toxicol. Environ. Health A., 1998, 54, 467.

[124] Kowluru, R.A.; Koppolu, P.; Chakrabarti, S.; Chen, S. Free Radic. Res., 2003, 37, 1169.

[125] Jennings, P.E.; Chirico, S.; Jones, A.F.; Lunec, J.; Barnett, A.H Diabetes Res., 1987, 6, 151

[126] Kowluru, R.A.; Kern, T.S.; Engerman, R.L. Free Radic. Biol. Med., 1997, 22, 587.

[127] Agardh, C.D.; Agardh, E.; Hultberg, B.; Qian, Y.; Ostenson, C.G. Curr. Eye Res., 1998, 17, 251

[128] Li, W.; Yanoff, M.; Jian, B.; He, Z. Cell Mol. Biol., 1999, 45, 59.

[129] Bursell, S.E.; King, G.L. Diabetes Res. Clin. Pract., 1999, 45, 169.

[130] Bursell, S.E.; Clermont, A.C.; Aiello, L.P.; Aiello, L.M.; Schlossman, D.K.; Feener, E.P.; Laffel, L.; King, G.L. Diabetes Care, 1999, 22, 1245.

[131] Ceriello, A.; Giugliano, D.; Quatraro, A.; Donzella, C.; Dipalo, G.; Lefebvre, P.J. Diabetes Care, 1991, 14, 68

[132] Paolisso, G.; D'Amore, A.; Galzerano, D.; Balbi, V.; Giugliano, D.; Varricchio, M.; D'Onofrio, F. Diabetes Care, 1993, 16, 1433

[133] Doly, M.; Droy-Lefaix, M.T.; Braquet, P. EXS., 1992, 62, 299.

[134] McCarty, M.F. Med. Hypotheses, 2005, 64, 159.

[135] Nemeth, B.; Hudomel, J.; Farkas, A. Ophthalmologica, 1975, 170 434.

[136] Leite, E.B.; Mota, M.C.; de Abreu, J.R.; Cunha-Vaz, J.G. Int Ophthalmol., 1990, 14, 81 .

[137] Berthet, P.; Farine, J.C.; Barras, J.P. Int. J. Clin. Pract., 1999, 53, 631.

[138] Rota, R., Chiavaroli, C.; Garay, R.P.; Hannaert, P. Eur. J. Pharmacol., 2004, 495, 217

[139] Brunet, J.; Farine, J.C.; Garay, R.P.; Hannaert, P. Fundam. Clin. Pharmacol., 1998, 12, 205.

[140] Graber, R.; Farine, J.C.; Losa, G.A. Apoptosis, 1998, 3, 41.

[141] Salama Benarroch, I.; Nano, H.; Perez, H.; Elizalde, F.; Bisceglia, H.; Salama, A. Ophthalmologica, 1977, 174, 47.

[142] Vojnikovic, B. Ophthalmic Res., 1991, 23, 12.

[143] Padilla, E.; Ganado, P.; Sanz, M.; Zeini, M.; Ruiz, E.; Trivino, A.; Ramirez, A.I.; Salazar, J.J.; Ramirez, J.M.; Rojas, B.; Hoz, Rd, R.; Tejerina, T. Diabetes Metab. Res. Rev., 2005, 21, 132.

[144] Klein, R.; Klein, B. E.; Lee, K. E.; Cruickshanks, K. J.; Moss, S. E Arch. Intern. Med. 1996, 156, 622.

[145] Migdalis, I.N.; Iliopoulou, V.; Kalageropolou, K.; Koutoulidis, K.; Samartzis, M. South Med. J., 1990, 83, 425. 
[146] Letizia, C.; Repossi, P.; Sellini, M.; Cerci, S.; Santi, G.; de Negri, A.M.; Pannarele, M.; Scavo, D. Int. J. Tissue React., 1992, 14, 299.

[147] Feman, S.S.; Mericle, R.A.; Reed, G.W.; May, J.M.; Workman, R.J. Am. J. Med. Sci., 1993, 305, 280.

[148] Van Dyk, D.J.; Erman, A.; Erman, T.; Chen-Gal, B.; Sulkes, J.; Boner, G. Eur. J. Clin. Invest., 1994, 24, 463.

[149] UKPDS Group. B.M.J., 1998, 317, 703.

[150] Suzuma, I.; Hata, Y.; Clermont, A.; Pokras, F.; Rook, S.L.; Suzuma, K.; Feener, E.P.; Aiello, L.P. Diabetes, 2001, 50, 444.

[151] Chaturvedi, N.; Sjolie, A-K.; Stephenson, J.M.; Abrahamian, H.; Keipes, M.; Castellarin, A.; Rogulja-Pepeonik, Z.; Fuller, J.H.; EUCLID Study Group. Lancet, 1998, 351, 28.

[152] Mori, F.; Hikichi, T.; Nagaoka, T.; Takahashi, J.; Yoshida, A.; Kitayan, N. Br. J. Ophthalmol., 2002, 86, 1172.

[153] Nagisa, Y.; Shintani, A.; Nakagawa, S. Diabetologia, 2001, 44, 883.

[154] Hogeboom van Buggenum, I.M.; Polak, B.C.; Reichert-Thoen, J.W.; De Vries-Knoppert, W.A.; van Hinsbergh, V.W.; Tangelder, G.J. Diabetologia, 2002, 45, 203.

[155] Abu el Asrar, A.M.; Maimone, D.; Morse, P.H.; Gregori, S.; Reder, A.T. Am. J. Ophthalmol., 1992, 114, 731.

[156] Yuuki, T.; Kanda, T.; Kimura, Y.; Kotafima, N.; Tamura, J.; Kobayashi, I.; Kishi, S. J. Diabetes Complications, 2001, 15, 257.

[157] Carmo, A.; Cunha-Vaz, J.G.; Carvalho, A.P.; Lopes, M.C. Vision Res., 1999, 39, 3817.

[158] Tilton, R.G.; Chang, K.; Hasan, K.S.; Smith, S.R.; Petrash, J.M. Misko, T.P.; Moore, W.M.; Currie, M.G.; Corbett, J.A.; McDaniel, M.L.; et al. Diabetes, 1993, 42, 221.

[159] Tang, J.; Mohr, S.; Du, Y.D.; Kern, T.S. Curr. Eye Res., 2003, 27 , 7.

[160] Joussen, A.M.; Poulaki, V.; Qin, W.; Kirchhif, B.; Mitsiades, N.; Wiegand, S.J.; Rudge, J.; Yancopoulos, G.D.; Adamis, A.P. Am. J. Pathol., 2002, 160, 501.

[161] Antonetti, D.A.; Barber, A.J; Khin, S.; Lieth, E.; Tarbell, J.M.; Gardner, T.W. Diabetes, 1998, 47, 1953.

[162] Barber, A.J.; Antonetti, D.A.; Gardner, T.W. Invest. Ophthalmol. Vis. Sci., 2000, 41, 3561 .

[163] Schroder, S.; Palinki, W.; Schmidt-Schonbein, G.W. Am. J.Pathol., 1991, 139,81 .

[164] McLeod, D.S.; Lefer, D.J.; Merges, C.; Lutty, G.A. Am. J. Pathol., 1995, 147, 642 .

[165] Joussen, A.M.; Murata, T.; Tsujikawa, A.; Kirchhof, B.; Bursell, S.E.; Adamis, A.P. Am. J. Pathol., 2001, 158, 147.

[166] Adamis, A.P. Br. J. Ophthalmol., 2002, 86, 363.

[167] Joussen, A.M.; Huang, S.; Poulaki, V.; Camphausen, K.; Beecken, W.D.; Kirchhof, B.; Adamis, A.P. Invest. Ophthalmol. Vis. Sci., 2001, 42, 3047.

[168] Bai, N.; Tang, S.; Ma, J., Luo, Y.; Lin, S. Yan Ke Xие Bao., 2003, 19, 176.

[169] Hughes, J.M.; Brink, A.; Witmer, A.N.; Hanraads-de Riemer, M.; Klaassen, I.; Schlingemann, R.O. Br. J. Ophthalmol., 2004, 88, 566.

[170] Barouch, F.C.; Miyamoto, K.; Allport, J.R.; Fujita, K.; Bursell, S.E.; Aiello, L.P.; Luscinskas, F.W.; Adamis, A.P. Invest. Ophthalmol. Vis. Sci., 2000, 41, 1153.

[171] Joussen, A.M.; Poulaki, V.; Le, M.L.; Koizumi, K.; Esser, C.; Janicki, H.; Schraermeyer, U.; Kociok, N.; Fauser, S.; Kirchhof, B.; Kern, T.S.; Adamis, A.P. FASEB J., 2004, 18, 1450.

[172] Tolentino, M.J.; Miller, J.W.; Gragoudas, E.S.; Jakobiec, F.A.; Flynn, E.; Chatzistefanou, K.; Ferrara, N.; Adamis, A.P. Ophthalmology, 1996, 103, 1820.

[173] Detmar, M.; Brown, L.F.; Schon, M.P.; Elicker, B.M.; Velasco, P.; Richard, L.; Fukamura, D.; Monsky, D.; Claffey, K.P.; Jain, R.K J. Invest. Dermatol., 1998, 111, 1.

[174] Lu, M.; Perez, V.; Ma, N.; Miyamoto, K.; Peng, H.B.; Liao, J.K.; Adamis, A.P. Invest. Ophthalmol. Vis. Sci., 1999, 40, 1808.

[175] Miyamoto, K.; Khosrof, S.; Bursell, S-E.; Moromizato, Y.; Aiello, L.P.; Ogura, Y.; Adamis, A.P. Am. J. Pathol., 2000, 156, 1733.

[176] Murata, T.; Nakagawa, K.; Khalil, A.; Ishibashi, T.; Inomata, H.; Sueishi, K. Lab. Invest., 1996, 74, 819.

[177] Amin, R.H.; Frank, R.N.; Kennedy, A.; Eliott, D.; Puklin, J.E.; Abrams, G.W. Invest. Ophthalmol. Vis. Sci., 1997, 38, 36.

[178] Radisavljevi, Z.; Avraham, H.; Avraham, S. J. Biol. Chem., 2000, $275,20770$.

[179] Mantovani, A.; Bussolino, F.; Introna, M. Immunol. Today, 1997, $18,231$.
[180] Kowluru, R.A.; Odenbach, S. Br. J. Ophthalmol., 2004, 88, 1343.

[181] Baynes, J.W. Diabetes, 1991, 40, 405.

[182] Taniyama, Y.; Griendling, K.K. Hypertension, 2003, 42, 1075.

[183] Vassilakopoulos, T.; Karatza, M.H.; Katsaounou, P.; Kollintza, A.; Zakynthinos, S.; Roussos, C. J. Appl. Physiol., 2003, 94, 1025.

[184] Hwang, Y.S.; Jeong, M.; Park, J.S.; Kim, M.H.; Lee, D.B.; Shin, B.A.; Mukaida, N.; Ellis, L.M.; Kim, H.R.; Ahn, B.W.; Jung, Y.D. Oncogene, 2004, 23, 6603.

[185] Scott, D.L. Int. J. Clin. Pract., 2005, 59, 114.

[186] Mohr, S.; Xi, X.; Tang, J.; Kern, T.S. Diabetes, 2002, 51, 1172.

[187] Chen, M.; Ona, V.O.; Li, M.; Ferrante, R.J.; Fink, K.B.; Zhu, S.; Bian, J.; Guo, L.; Farrell, L.A.; Hersch, S.M.; Hobbs, W.; Vonsattel, J.P.; Cha, J.H.; Friedlander, R.M. Nat. Med., 2000, 6, 797.

[188] Zhu, S.; Stavrovskaya, I.G.; Drozda, M.; Kim, B.Y.; Ona, V.; Li, M.; Sarang, S.; Liu, A.S.; Hartley, D.M.; Wu du, C.; Gullans, S.; Ferrante, R.J.; Przedborski, S.; Kristal, B.S.; Friedlander, R.M. Nature, 2002, 417, 74.

[189] Barnes, P.J. Clin. Sci. (Lond), 1998, 94, 557.

[190] Penfold, P.L.; Wen, L.; Madigan, M.C.; Gillies, M.C.; King, N.J.; Provis, J.M. Clin. Exp. Immunol., 2000, 121, 458.

[191] Colwell, J.A.; Halushka, P.V.; Sarji, K.; Levine, J.; Sagel, J.; Nair, R.M. Diabetes, 1976, 25, 826.

[192] Pope, C.H. Diabetes, 1960, 9, 9.

[193] Powell, E.D.U.; Field, R.A. Lancet, 1964, 2, 17.

[194] Boeri, D.; Maiello, M.; Lorenzi, M. Diabetes, 2001, 50, 1432

[195] Kern, T.S.; Engerman, R.L. Diabetes, 2001, 50, 1636.

[196] Boudoin, C.; Passa, Ph.; Sharp, P.; Kohner, E.M. Diabetes, 1989, $38,491$.

[197] Early Treatment of Diabetic Retinopathy Study Group. Ophthalmology, 1991, 98, 757.

[198] Hollis, T.M.; Gardner, T.W.; Vergis, G.J.; Kirbo, B.J.; Butler, C.; Dull, R.O.; Campos, M.J.; Enea, N.A. J. Diabet. Complications, 1988, $2,47$.

[199] Enea, N.A.; Hollis, T.M.; Kern, J.A.; Gardner, T.W. Arch. Ophthalmol., 1989, 107, 270

[200] Gardner, T.W.; Eller, A.W.; Friberg, T.R.; D'Antonio, J.A.; Hollis, T.M. Retina, 1995, 15, 134.

[201] Carroll, W.J.; Hollis, T.M.; Gardner, T.W. Invest. Ophthalmol. Vis. Sci., 1988, 29, 1201.

[202] Hollis, T.M.; Sill, H.W.; Butler, C.; Campos, M.J.; Gardner, T.W. J. Diabetes Complications, 1992, 6, 230.

[203] Gastinger, M.J.; Barber, A.J.; Khin, S.A.; McRill, C.S.; Gardner, T.W.; Marshak, D.W. Invest. Ophthalmol. Vis. Sci., 2001, 42, 2679.

[204] Gardner, T.W. Trans. Am. Ophthalmol. Soc., 1995, 93, 583.

[205] Patnaik, R.; Mohanty, S.; Sharma, H.S. Acta Neurochir. Suppl., 2000, 76, 535 .

[206] Daley, M.L.; Watzke, R.C.; Riddle, M.C. Diabetes Care, 1987, 10 , 777.

[207] Roy, M.S.; Gunkel, R.D.; Podgor, M.J. Arch. Ophthalmol., 1986, $104,225$.

[208] Sokol, S.; Moskowitz, A.; Skarf, B.; Evans, R.; Molitch, M.; Senior, B. Arch. Ophthalmol., 1985, 103, 51

[209] Barber, A.J.; Lieth, E.; Khin, S.A.; Antonetti, D.A.; Buchanan, A.G.; Gardner, T.W. J. Clin. Invest., 1998, 102, 783.

[210] Aizu, Y.; Oyanagi, K.; Hu, J.; Nakagawa, H. Neuropathology, 2002, 22, 161 .

[211] Abu el Asrar, A.M.; Dralands, L.; Missotten, L.; Al-Jadaan, I.A.; Geboes, K. Invest. Ophthalmol. Vis. Sci., 2004, 45, 2760.

[212] Martin, P.M.; Roon, P.; Van Ells, T.K.; Ganapathy, V.; Smith, S.B Invest. Ophthalmol. Vis. Sci., 2004, 45, 3330.

[213] Brafman, A.; Mett, I.; Shafir, M.; Gottlieb, H.; Damari, G.; Gozlan-Kelner, S.; Vishnevskia-Dai, V.; Skaliter, R.; Einat, P.; Faerman, A.; Feinstein, E.; Shoshani, T. Invest. Ophthalmol. Vis. Sci., 2004, 45, 3796.

[214] Ozawa, S.; Kamiya, H.; Tsuzuki, K. Prog. Neurobiol., 1998, 54 , 581.

[215] Ferreira, I.L.; Duarte, C.B.; Carvalho, A.P. Neuroreport, 1998, 9, 3471.

[216] Vorwerk, C.K.; Gorla, M.S.; Dreyer, E.B. Surv. Ophthalmol., 1999, 43, S142.

[217] Wong, P. Biochem. Cell. Biol., 1994, 72, 489.

[218] Lieth, E.; Barber, A.J.; Xu, B.; Dice, C.; Ratz, M.J.; Tanase, D.; Strother, J.M. Diabetes, 1998, 47, 815 . 
[219] Ambati, J.; Chalam, K.V.; Chawla, D.K.; D'Angio, C.T.; Guillet, E.G.; Rose, S.J.; Vanderlinde, R.E.; Ambati, B.K. Arch. Ophthalmol., 1997, 115, 1161.

[220] Deng, J.; Wu, D.Z.; Gao, R Yan Ke Xие Bao, 2000, 16, 199.

[221] Asensio Sanchez, V.M.; Corral Azor, A.; Aguirre Aragon, B., De Paz Garcia, M. Arch. Soc. Esp. Oftalmol., 2003, 78, 493.

[222] Gorovits, R.; Avidan, N.; Avisar, N.; Shaked, I.; Vardimon, L. Proc. Natl. Acad. Sci. USA, 1997, 94, 7024.

[223] Lieth, E.; LaNoue, K.F.; Antonetti, D.A.; Ratz, M. Exp. Eye Res., 2000, 70, 723 .

[224] Li, Q.; Puro, D.G. Invest. Ophthalmol. Vis. Sci., 2002, 43, 3109.

[225] Reisberg, B.; Doody, R.; Stoffler, A.; Schmitt, F.; Ferris, S.; Mobius, H.J. N. Engl. J. Med., 2003, 348, 1333.

[226] Vorwerk, C.K.; Lipton, S.A.; Zurakowski, D.; Hyman, B.T.; Sabel, B.A.; Dreyer, E.B. Invest. Ophthalmol. Vis. Sci., 1996, 37, 1618.

[227] Lipton, S.A. Neurorx., 2004, 1, 101.

[228] Zurakowski, D.; Vorwerk, C.K.; Gorla, M.; Kanellopoulos, A.J.; Chaturvedi, N.; Grosskreutz, C.L.; Lipton, S.A.; Dreyer, E.B. Vision, Res., 1998, 38, 1489.

[229] Reiter, C.E.; Gardner, T.W. Prog. Retin. Eye Res., 2003, 22, 545.

[230] Gosbell, A.D.; Favilla, I.; Jablonski, P. Clin. Experiment Ophthalmol., 2002, 30, 124.

[231] Diaz, B.; Serna, J.; De Pablo, F.; De La Rosa, E.J. Development, 2000, 127, 1641.

[232] Diaz, B.; Pimentel, B.; De Pablo, F.; De La Rosa, E.J. Eur. J. Neurosci., 1999, 11, 1624.
[233] Barber, A.J.; Nakamura, M.; Wolpert, E.B.; Reiter, C.E.; Seigel, G.M.; Antonetti, D.A.; Gardner, T.W. J. Biol. Chem., 2001, 276 , 32814.

[234] Dahl-Jorgensen, K.; Brinchmann-Hansen, O.; Hanssen, K.F.; Sandvik, L.; Aagenaes, O. Br. Med. J. (Clin. Res. Ed.), 1985, 290, 811.

[235] Lauritzen, T.; Frost-Larsen, K.; Larsen, H.W.; Deckert, T. Diabetes, 1985, 34, 74 .

[236] Roysarkar, T.K.; Gupta, A.; Dash, R.J.; Dogra, M.R. Am. J. Ophthalmol., 1993, 115, 569.

[237] Kondo, T.; Vicent, D.; Suzuma, K.; Yanagisawa, M.; King, G.L.; Holzenberger, M.; Kahn, C.R. J. Clin. Invest., 2003, 111, 1835.

[238] The Diabetes Control and Complications Trial/Epidemiology of Diabetes Interventions and Complications Research Group. $N$. Engl. J. Med., 2000, 342, 381.

[239] Chao, M.V. Nat. Ver. Neurosci., 2003, 4, 299.

[240] Lindsay, R.M., Wiegand, S.J., Altar, C.A. ; DiStefano, P.S. Trends Neurosci., 1994, 17, 182.

[241] Aguayo, A.J.; Clarke, D.B.; Jelsma, T.N.; Kittlerova, P.; Friedman, H.C.; Bray, G.M. Ciba Found Symp., 1996, 196, 135.

[242] Reh, T.A.; McCabe, K.; Kelley, M.W.; Bermingham-McDonogh, O. Ciba. Found. Symp., 1996, 196, 120.

[243] Seki, M.; Tanaka, T.; Nawa, H.; Usui, T.; Fukuchi, T.; Ikeda, K.; Abe, H.; Takei, N. Diabetes, 2004, 53, 2412.

[244] Wellmer, A.; Misra, V.P.; Sharief, M.K.; Kopelman, P.G.; Anand, P. J. Peripher. Nerv. Syst., 2001, 6, 204. 